\title{
Follistatin-Related Protein 1
}

National Cancer Institute

\section{Source}

National Cancer Institute. Follistatin-Related Protein 1. NCI Thesaurus. Code C131547.

Follistatin-related protein 1 (308 aa, $\sim 35 \mathrm{kDa}$ ) is encoded by the human FSTL1 gene. This protein is involved in both signaling pathways and binding to heparin. 